Salt Lakes 


\title{
Developments in Hydrobiology 5
}

\author{
Series editor \\ H. J. Dumont
}

DR W. JUNK PUBLISHERS THE HAGUE-BOSTON-LONDON 1981 


\title{
Salt Lakes
}

Proceedings of the International Symposium on Athalassic (Inland) Salt Lakes, held at Adelaide, Australia, October 1979

\author{
Edited by \\ W. D. Williams
}

Reprinted from Hydrobiologia, vols. 81/82 (1981)

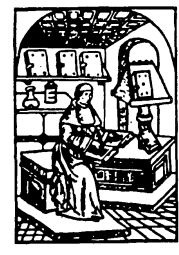

DR W. JUNK PUBLISHERS THE HAGUE-BOSTON-LONDON 1981 


\section{Distributors:}

for the United States and Canada

Kluwer Boston, Inc.

190 Old Derby Street

Hingham, MA 02043

U.S.A.

for all other countries

Kluwer Academic Publishers Group

Distribution Center

P.O. Box 322

3300 AH Dordrecht

The Netherlands

This volume is listed in the Library of Congress Cataloging in Publication Data

ISBN-13: 978-94-009-8667-1

e-ISBN-13: 978-94-009-8665-7

DOI:10.107/978-94-009-8665-7

Cover design: Max Velthuijs

Copyright o 1981, Dr W. Junk Publishers, The Hague

Softcover reprint of the hardcover 1st Edition 1981

All rights reserved. No part of this publication may be reproduced, stored in a retrieval system, or transmitted in any form or by any. means, mechanical, photocopying, recording, or otherwise, without the prior written permission of the publishers

Dr W. Junk Publishers, P.O. Box 13713, 2501 ES The Hague. The Netherlands. 


\section{Foreword}

This publication is composed of papers presented at an International Symposium on Athalassic (Inland) Salt Lakes, which was hosted by the University of Adelaide, South Australia, during a week in October 1979. The genesis of the Symposium was at the Copenhagen Congress of the International Association of Limnology (S.I.L.) where it was noted that a number of papers concerned with inland saline lakes were distributed throughout sessions in such a way as to make it difficult to attend all of them. A number of participants at the Congress felt that the ecology of salt lakes had greater homogeneity or cohesiveness than this sort of distribution would suggest, and it was decided that a symposium on salt lakes be held.

The symposium was the first under the aegis of the S.I.L. to be held in Australia, and it was very well attended, with participants coming from many countries. The week long programme produced a number of lively and interesting sessions on all aspects of athalassic saline lakes. Participants stayed on after the Symposium for an expedition to Lake Eyre, in the nørth of South Australia, and were given one of the best of all possible introductions to the Australian environment.

The Symposium was supported by a grant from the University of Adelaide. The University of Adelaide is the third oldest in Australia, having been founded in 1874, and it places a high value on promoting research across the whole spectrum of knowledge. It enjoys a high reputation for research excellence and attracts an outstanding share of government and privately allocated research monies in Australia. In addition, where it can, the University offers financial support of its own to activities related to the research interests of its staff. We were honoured and delighted to be able to host this Symposium which provided an opportunity for an exchange of ideas and discussion between colleagues working in related fields of interest in many different regions of the world. It is essential that researchers are able to maintain a broad vision of the way in which research in their field is developing. Conferences are an important means of achieving this end.

It is my hope that there will be many more international symposia such as this one, and that the experiences of Adelaide, and the publication of these proceedings will form an important background to encouraging further development of international research and cooperation in the field.

D. R. Stranks

Vice-Chancellor,

University of Adelaide 


\section{Editor's preface}

The claim that the total volume of inland saline water is not substantially less than that of inland fresh water comes as a surprize to most limnologists, for traditionally (indeed, almost by definition) limnology is the study of fresh waters. Of course, this is understandable in that fresh water is often the only sort of inland water near most limnologists, and in terms of man's need for water is much more important than saline water.

The general lack of awareness a mongst limnologists concerning the abundance of inland saline waters is reflected, predictably, in the relatively small amount of attention that has been accorded them. Yet salt lakes have many features of limnological interest as well as considerable economic significance. Recognizing in particular the biological interest of salt lakes, a group of participants at the Copenhagen congress of Societas Internationalis Limnologiae (S.I.L.) decided to convene a symposium in which the dominant theme would be the biology of salt lakes. In this way, it was hoped, increased attention would be drawn to the subject, an opportunity would be provided to review information presently available, and other limnologists might be stimulated to research this neglected but fascinating field of limnology. The organization of the symposium was left to Dr I. A. E. Bayly, Prof. U. T. Hammer and myself.

It was decided to hold the symposium in Australia, an apposite choice of venue on several grounds. Australia has many salt lakes and overall they are more common than freshwater lakes; and limnology in Australia is a young but growing discipline so that there is a certain sense of timeliness that the first Australian S. I. L. symposium should be about salt lakes. In due course, the symposium took place and some fifty limnologists from ten countries participated (see List of Participants). The formal proceedings occurred over five days (22-26 October, 1979), and were followed by an expedition to Lake Eyre and other salt lakes in South Australia (led by me), and then to some salt lakes in western Victoria (led by Dr I. A. E. Bayly).

This book results from the formal proceedings, and with its publication I hope the major aims of the symposium will be achieved. A few papers are also published here which were not actually read at the symposium; they are, however, by authors who planned to attend but who were prevented from doing so by last-minute and unforeseen circumstances, or by authors who did attend but who for various good reasons did not read the paper now published. Originally, it was hoped to include in the published proceedings edited versions of the sometimes lengthy discussions which followed the reading of papers. Several reasons (but principally space requirements) have precluded this.

During the symposium and following expedition, a number of my colleagues at the University of Adelaide gave valuable support. Particular acknowledgement is made of the tremendous and unstinting support of Patrick De Deckker, but also gratefully acknowledged is the support of K. F. Walker, D. J. Williams and Miss Sandra Lawson. Mrs Rathman, Manageress of the Rymill Conference Centre, where the symposium was held, is thanked for her hospitality, and the many small kindnesses which ensured that the non-cerebral cares of participants were not a constraint to the success of the symposium.

The publication of the proceedings would not have been possible without the enthusiastic support and help of many people. Especially do I thank Miss Sandra Lawson, Secretary to the Department of Zoology, University of Adelaide, for her meticulous typing and attention to many related matters. Almost all figures were redrawn by Mrs Ruth Hughes, and rephotographed by Mr Phil Kempster, also of the University of Adelaide; they, too, are sincerely thanked. 
All papers here were critically assessed by a number of colleagues before acceptance. In this regard, I gratefully acknowledge the help of I. A. E. Bayly (Monash University, Australia), L. C. Beadle (The University, Newcastle Upon Tyne, U.K.), L. J. Borowitzka (Roche Research Institute of Marine Pharmacology, Australia), T. D. Brock (University of Wisconsin, U.S.A.), H. Caspers (Institut für Hydrobiologie und Fischereiwissenschaft, Hamburg, Western Germany), P. De Deckker (University of Adelaide, Australia), J. Dorgelo (University of Amsterdam, The Netherlands), H. J. Dumont (Rijksuniversiteit, Gent, Belgium), C. Ellis-Evans (British Antarctic Survey, Cambridge, U.K.), G. Fryer, FRS (Freshwater Biological Association, U.K.), G. G. Ganf (University of Adelaide, Australia), M. C. Geddes (University of Adelaide, Australia), U. T. Hammer (University of Saskatchewan, Canada), G. Hartmann (Universität Hamburg, Western Germany), C. den Hartog (Katholieke Universiteit, Nijmegen, The Netherlands), R. B. Heywood (British Antarctic Survey, Cambridge, U.K.), H. B. N. Hynes (University of Waterloo, Canada), R. Marchant (University of Adelaide, Australia), J. W. Neale (University of Hull, U.K.), F. J. Post (Utah State University, U.S.A.), D. Thomas (University of Tasmania, Australia), Winifred A. Tutin, FRS (University of Leicester, U.K.), P. A. Tyler (University of Tasmania, Australia) and K. F. Walker (University of Adelaide, Australia).

Finally, I thank the University of Adelaide for financial support towards the symposium, and for the less tangible but none the less important support of its Vice-Chancellor, Professor D. R. Stranks.

W. D. Williams 


\section{Contents}

Foreword,

by D. R. Stranks

Editor's Preface,

by W. D. Williams

List of Participants $\quad$ XIII

1. Inland Salt Lakes: An Introduction, by W. D. Williams 1

2. Aquatic Plant Communities of Poikilosaline Waters, by C. Den Hartog 15

3. The Ecology of Halophytes in the South-East of South Australia, by Margaret A. Brock

4. The Microflora: Adaptations to Life in Extremely Saline Lakes, by Lesley J. Borowitzka

5. Primary Production in Saline Lakes: A Review, by $\mathrm{U}$. Theodore Hammer

6. Microbiology of the Great Salt Lake North Arm, by F. J. Post

7. Photosynthetic Activity of Phytoplankton in Tropical African Soda Lakes, by John M. Melack

8. Occurrence of Benthic Microbial Mats in Saline Lakes, by $\mathrm{J}$. Bauld

9. Blood Osmoregulation and Temperature in Crustaceans, by J. Dorgelo

10. Ostracods of Athalassic Saline Lakes: A Review, by Patrick De Deckker 
11. Responses of a Calanoid Copepod to Existence in Saline Waters, by Geoffrey W. Brand

12. The Interaction of Salinity, Predators, Light and Copepod Color, by Nelson G. Hairston, Jr.

13. A Synopsis of Ecological Information on the Saline Lake Rotifer Brachionus plicatilis Müller 1786, by K. F. Walker

14. The Brine Shrimps Artemia and Parartemia: Comparative Physiology and Distribution in Australia,

by M. C. Geddes

15. Animal Communities in Three Victorian Lakes of Differing Salinity, by B. V. Timms

16. On the Chemistry of Some Salt Lakes and Ponds in Yugoslavia, by Grozdana Petrović

17. On the Chemistry and Biota of Some Saline Lakes in Western Australia,

by M. C. Geddes, P. De Deckker, W. D. Williams, D. W. Morton and M. Topping

18. The Ecology of Plankton Fauna in Saline River Pools, by R. J. Rippingale

19. The Limnology of Saline Lakes in Western Victoria: A Review of Some Recent Studies, by W. D. Williams

20. On the Ecology of Hypersaline Lagoons on Laysan Atoll and Kauai Island, Hawaii, with Special Reference to the Laysan Duck, Anas lay'sanensis Rothschild, by H. Caspers

21. Kratergöl, a Deep Hypersaline Crater-Lake in the Steppic Zone of Western Anatolia (Turkey), Subject to Occasional Limno-meteorological Perturbations, by H. J. Dumont

22. Limnology of a Large, Deep, North American Terminal Lake, Pyramid Lake, Nevada, U.S.A., by D. L. Galat, E. L. Lider, S. Vigg and S. R. Robertson

23. The Biology of Antarctic Saline Lakes, by S. W. Wright and H. R. Burton

24. Chemistry, Physics and Evolution of Antarctic Saline Lakes: A Review, by H. R. Burton

25. Microbial Ecology of an Antarctic Saline Meromictic Lake, by R. M. Hand and H. R. Burton

26. Saline Lakes at Syowa Oasis, Antarctica, by $\mathrm{H}$. Tominaga and F. Fukui 
27. Biotechnology of Solar Saltfields,

by A. G. Jones, C. M. Ewing and M. V. Melvin

28. Palaebiogeography of Some Salt Lake Faunas, by K. G. McKenzie

29. Late Quaternary Pollen Records and Seasonal Palaeo Climates of Lake Frome, South Australia, by Gurdip Singh

30. Australian Salt Lakes: A Palaeohydrologic Approach, by J. M. Bowler 

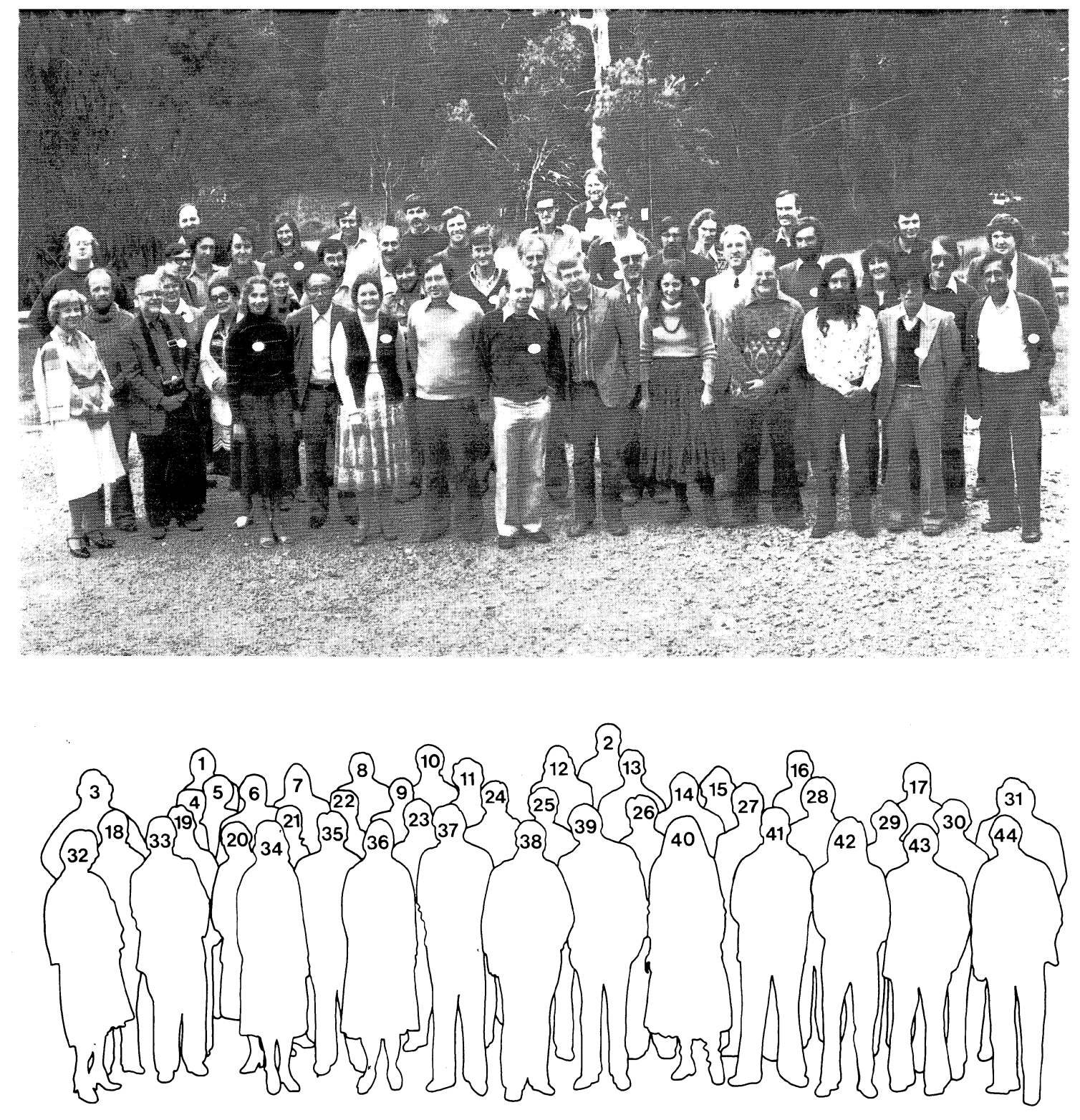

Group photograph. For key to numbers see list of participants. 


\section{List of participants*}

L. Barmuta (15), Monash University, Melbourne, Australia.

J. Bauld, Baas-Becking Geobiological Laboratory, Canberra, Australia.

I. A. E. Bayly (6), Monash University, Melbourne, Australia.

J. A. H. Benzie (23), Australian National University, Canberra, Australia.

P. Birch (30), Department of Conservation and the Environment, Perth, Australia.

L. J. Borowitzka (36), Roche Research Institute of Marine Pharmacology, Sydney, Australia.

J. M. Bowler (2), Australian National University, Canberra, Australia.

G. W. Brand, The Ministry for Conservation, Melbourne, Australia.

M. Brock (40), University of Adelaide, Adelaide, Australia.

M. F. Buonaiuto, University of Adelaide, Adelaide, Australia.

R. V. Burne (39), Bureau of Mineral Resources, Canberra, Australia.

H. Burton (1), Antarctic Division, Melbourne, Australia.

R. A. Callen, Department of Mines and Energy, Adelaide, Australia.

H. Caspers (26), Institut für Hydrobiologie und Fischereiwissenschaft, Universität Hamburg, Western Germany.

P. De Deckker (38), University of Adelaide, Adelaide, Australia.

J. Dorgelo (8), University of Amsterdam, The Netherlands.

H. J. Dumont (37), Rijksuniversiteit, Gent, Belgium.

C. Ellis-Evans, British Antarctic Survey, Cambridge, U. K.

C. M. Ewing, ICI Australia Ltd, Melbourne, Australia.

N. Fisher (5), The Ministry for Conservation, Melbourne, Australia.

D. L. Galat, University of Colorado, Colorado, U.S.A.

K. Hamilton-Galat, University of Colorado, Colorado, U.S.A.

N. G. Hairston, Jr. (31), University of Rhode Island, Rhode Island, U.S.A.

U. T. Hammer (41), University of Saskatchewan, Saskatoon, Canada.

R. Hamond (3), University of Melbourne, Melbourne, Australia.

R. M. Hand (16), Antarctic Division, Melbourne, Australia.

C. den Hartog (25), Katholieke Universiteit, Nijmegen, The Netherlands.

R. B. Heywood (11), British Antarctic Survey, Cambridge, U.K.

S. Horie (35), Kyoto University, Kyoto, Japan.

S. Humphries (21), Australian National University, Canberra, Australia.

S. H. Hurlbert (10), San Diego State University, California, U.S.A.

M. Johnson (34), Department of Mineral Resources and Development, Sydney, Australia.

K. G. McKenzie (9), Riverina College of Advanced Education, Wagga Wagga, Australia.

P. Macumber (42), Department of Minerals and Energy, Melbourne, Australia.

R. Marchant (28), University of Adelaide, Adelaide, Australia.

* The key to the group photograph is given by the number in brackets after names. 
T. G. Marples (13), Australian National University, Canberra, Australia.

K. F. Ngian (43), ICI Australia Ltd, Melbourne, Australia.

G. Petrovic (32), Institute for Biological Research, Beograd, Yugoslavia.

F. J. (33) and Mrs (19) Post, Utah State University, Logan, U.S.A.

I. J. Powling (7), State Rivers and Water Supply Commission, Melbourne, Australia.

R. J. Rippingale (24), Western Australian Institute of Technology, Perth, Australia.

A. Ruttner-Kolisko (20), Biologische Station, Lunz, Austria.

J. F. Saunders, State Rivers and Water Supply Commission, Melbourne, Australia.

G. Singh (44), Australian National University, Canberra, Australia.

G. Steffanson (14), Engineering and Water Supply Department, Adelaide, Australia.

B. V. Timms (4), Avondale College, Cooranbong, Australia.

K. F. Walker (17), University of Adelaide, Adelaide, Australia.

D. Williams, Flinders University, Adelaide, Australia.

W. D. Williams (27), University of Adelaide, Adelaide, Australia.

S. Wright (22), Antarctic Division, Melbourne, Australia. 